\title{
Soil carbon release responses to long-term versus short-term climatic warming in an arid ecosystem
}

\author{
Hongying Yu ${ }^{1,2}$, Zhenzhu $\mathrm{Xu}^{1}$, Guangsheng Zhou ${ }^{1,3}$, and Yaohui Shi ${ }^{1,3}$ \\ ${ }^{1}$ State Key Laboratory of Vegetation and Environmental Change, Institute of Botany, Chinese Academy of Sciences, \\ Beijing 100093, China \\ ${ }^{2}$ University of Chinese Academy of Sciences, Beijing, 100049, China \\ ${ }^{3}$ Chinese Academy of Meteorological Sciences, China Meteorological Administration, Beijing 100081, China
}

Correspondence: Zhenzhu Xu (xuzz@ibcas.ac.cn) and Guangsheng Zhou (zhougs@cma.gov.cn)

Received: 11 June 2019 - Discussion started: 18 July 2019

Revised: 14 January 2020 - Accepted: 20 January 2020 - Published: 17 February 2020

\begin{abstract}
Climate change severely impacts the grassland carbon cycling by altering rates of litter decomposition and soil respiration $\left(R_{\mathrm{S}}\right)$, especially in arid areas. However, little is known about the $R_{\mathrm{S}}$ responses to different warming magnitudes and watering pulses in situ in desert steppes. To examine their effects on $R_{\mathrm{S}}$, we conducted long-term moderate warming (4 years, $\sim 3^{\circ} \mathrm{C}$ ), short-term acute warming (1 year, $\sim 4^{\circ} \mathrm{C}$ ) and watering field experiments in a desert grassland of northern China. While experimental warming significantly reduced average $R_{\mathrm{S}}$ by $32.5 \%$ and $40.8 \%$ under long-term moderate and short-term acute warming regimes, respectively, watering pulses (fully irrigating the soil to field capacity) stimulated it substantially. This indicates that climatic warming constrains soil carbon release, which is controlled mainly by decreased soil moisture, consequently influencing soil carbon dynamics. Warming did not change the exponential relationship between $R_{\mathrm{S}}$ and soil temperature, whereas the relationship between $R_{\mathrm{s}}$ and soil moisture was better fitted to a sigmoid function. The belowground biomass, soil nutrition, and microbial biomass were not significantly affected by either long-term or short-term warming regimes, respectively. The results of this study highlight the great dependence of soil carbon emission on warming regimes of different durations and the important role of precipitation pulses during the growing season in assessing the terrestrial ecosystem carbon balance and cycle.
\end{abstract}

\section{Introduction}

The global carbon (C) cycle is a critical component of the earth's biogeochemical processes and plays a major role in global warming, which is mainly exacerbated by the elevated carbon dioxide $\left(\mathrm{CO}_{2}\right)$ concentration in the atmosphere (e.g., Falkowski et al., 2000; Carey et al., 2016; Ballantyne et al., 2017; Meyer et al., 2018). Soil respiration $\left(R_{\mathrm{S}}\right)$, mainly consisting of the respiration of live roots and microorganisms, is a key component of the ecosystem $\mathrm{C}$ cycle as it releases ca. $80 \mathrm{Pg}$ of $\mathrm{C}$ from the pedosphere to the atmosphere annually (Boone et al., 1998; Karhu et al., 2014; L. Liu et al., 2016; Ma et al., 2014; Schlesinger, 1977). The effects of both soil moisture and temperature on $R_{\mathrm{S}}$ processes and the ecophysiological mechanism have been reported on extensively; however, it is not well known how soil moisture modulates the response of $R_{\mathrm{S}}$ to changes in the duration and intensity of warming, particularly in arid and semiarid areas, where water and nutrients are both severely limited (e.g., Dacal et al., 2019; Fa et al., 2018; Reynolds et al., 2015; Ru et al., 2018).

The desert steppe of China is ca. 88 million $\mathrm{hm}^{2}$, accounting for $22.6 \%$ of all grasslands in China, and is located in both arid and semiarid areas. More than $50 \%$ of the total area of the steppe faces severe degradation in terms of the decline of community productivity and soil nutrient depletion, primarily due to improper land use, such as overgrazing and adverse climatic changes, including heat waves and drought stresses (Bao et al., 2010; Kang et al., 2007; Yu et al., 2014). Global surface temperature - mainly caused by anthropogenic $\mathrm{CO}_{2}$ increase - is expected to increase 
from 2.6 to $4.8^{\circ}$ by the end of this century, accelerating land degradation (IPCC, 2014, 2019). Moreover, the desert steppe ecosystem with low vegetation productivity is vulnerable to harsh environmental conditions, such as scarce precipitation and barren soil nutrition. For instance, water deficit and heat waves during the growing season can markedly decrease plant cover and productivity in this arid ecosystem (Hou et al., 2013; Maestre et al., 2012; Yu et al., 2018).

Numerous studies have shown that soil temperature and moisture are the two main, crucial factors that control $R_{\mathrm{s}}$; however, it is not well known how soil moisture status mediates the response of $R_{\mathrm{S}}$ to the changes in the duration and intensity of climatic warming. Soil temperature is the primary factor driving temporal $R_{\mathrm{S}}$ variations (e.g., Carey et al., 2016; Gaumont-Guay et al., 2006; Li et al., 2008; Wan et al., 2005). Generally, $R_{\mathrm{S}}$ is significantly and positively correlated with soil temperature when soil moisture is ample (Curiel et al., 2003; Jia et al., 2006; Lin et al., 2011; Reynolds et al., 2015; Yan et al., 2013). In general, the seasonal variations of $R_{\mathrm{S}}$ coincide with the seasonal patterns of soil temperature (Keith et al., 1997; Lin et al., 2011; Wan et al., 2007). For instance, Lin et al. (2011) reported that $63 \%$ to $83 \%$ of seasonal variations of $R_{\mathrm{S}}$ are dominantly controlled by soil temperature. Diurnal $R_{\mathrm{S}}$ variations are highly associated with variations in soil temperature (Drewitt et al., 2002; Jia et al., 2006; Song et al., 2015). Soil respiration, according to previous studies, is expected to increase with soil water content (SWC; e.g., Chen et al., 2008; Song et al., 2015; Wan et al., 2007; Yan et al., 2013). However, when the SWC exceeds the optimal point to reach saturated levels, $R_{\mathrm{S}}$ decreases (Huxman et al., 2004; Kwon et al., 2019; Moyano et al., 2012, 2013; Wang et al., 2014; Yan et al., 2018). In a study conducted in a tall grass prairie, water addition dramatically increased soil $\mathrm{CO}_{2}$ efflux (Liu et al., 2002). Liu et al. (2009) showed a significant $R_{\mathrm{S}}$ increase after a precipitation pulse in a typical temperate steppe. Therefore, in arid and semiarid regions, where soil water is limited, the SWC may control $R_{\mathrm{S}}$, and regulate the warming effect (Chen et al., 2008; Curiel et al., 2003; Shen et al., 2015). Furthermore, the effect of watering pulses depends on the pulse size, antecedent soil moisture conditions, soil texture and plant cover (Cable et al., 2008; Chen et al., 2008; Shen et al., 2015; Hoover et al., 2016). For instance, the results by Huxman et al. (2004) showed that different precipitation pulses have different effects on carbon fluxes in these arid and semiarid regions; Sponseller (2007) indicated that $\mathrm{CO}_{2}$ efflux increases with storm size in a Sonoran Desert ecosystem.

A previous study has indicated that short-term (2-year) warming $\left(2^{\circ} \mathrm{C}\right)$ did not affect significantly respiration rate during the growing season (T. Liu et al., 2016). However, there is limited information about long-term (4-year) warming effects on $R_{\mathrm{S}}$ and the underlying mechanism. In this study, we expect that long-term (4-year) warming may have more profound effects on $R_{\mathrm{S}}$ relative to previous 2 -year shortterm warming; and the underlying mechanism under longer- term warming conditions, and the role of soil water status in $R_{\mathrm{S}}$ responses to climatic warming are also required to be explored further. Thus, in the present study, we used a randomized block design with three treatments: control (no warming, no watering), long-term moderate warming (4 years extending from 2011 to 2014) and short-term acute warming (1 year in 2014). Moreover, a watering pulse treatment (full irrigation to reach field capacity) was also established. We present the following hypotheses: (i) both long- and shortterm climatic warming can reduce soil $\mathrm{CO}_{2}$ efflux, in which decreased soil moisture plays a key role in reducing $R_{\mathrm{S}}$ in the arid ecosystem; and (ii) the dynamics of $R_{\mathrm{S}}$ in the waterlimited ecosystem can be driven mainly by the combination of soil temperature and soil moisture, and soil moisture can modulate the response of $R_{\mathrm{S}}$ to warming.

\section{Methods and materials}

\subsection{Experimental site}

The experiment was conducted in a desert steppe about $13.5 \mathrm{~km}$ from Bailingmiao in Damao County $\left(110^{\circ} 19^{\prime} 53.3^{\prime \prime} \mathrm{E}, 41^{\circ} 38^{\prime} 38.3^{\prime \prime} \mathrm{N} ; 1409 \mathrm{~m}\right.$ above sea level), situated in Nei Mongol, northern China. This area is characterized by a typical continental climate. The mean annual temperature of this area was $4.3^{\circ} \mathrm{C}$ with a minimum of $-39.4^{\circ} \mathrm{C}$ and a maximum of $38.1^{\circ} \mathrm{C}$ from 1955 to 2014 . The mean annual precipitation is $256.4 \mathrm{~mm}$ and approximately $70 \%$ of the annual precipitation is distributed in the growth season period occurring from June to August (Fig. S1 in the Supplement). According to Chinese classification, the soil type is called "chestnut" (Calcic Kastanozems in the FAO soil classification) with a bulk density of $1.23 \mathrm{~g} \mathrm{~cm}^{-3}$ and a $\mathrm{pH}$ of 7.4. The area has not been grazed since 1980; the dominant species is Stipa tianschanica var. klemenzii, accompanied by Cleistogenes squarrosa, Neopallasia pectinata, Erodium stephanianum and Artemisia capillaris (e.g., Hou et al., 2013; Ma et al., 2018).

\subsection{Experimental design}

The warming experiment used a randomized block design. The long-term moderate warming plots were exposed to long-term warming from early June to late August (the growing season) for 4 years (2011-2014), while short-term acute warming was manipulated only during the growing season (June to August) in 2014. The targeted increases in temperatures relative to ambient temperature (control) are around 3 and $4{ }^{\circ} \mathrm{C}$ under the long-term moderate warming (4 years) and short-term acute warming regimes (1 year), respectively. Watering pulse treatments were conducted in August in 2014 and 2017. The control plots received no additional treatments of either temperature or water (they were recognized as warming or watering control treatments). All of the warmed plots were heated $24 \mathrm{~h} \mathrm{~d}^{-1}$ by infrared (IR) lamps $(1.0 \mathrm{~m}$ 
long; GHT220-800; Sanyuan Huahui Electric Light Source Co. Ltd., Beijing, China) at $800 \mathrm{~W}$ during growing seasons in the experiment's years (2011-2014). The IR lamp heights above the ground were 1.5 and $1.0 \mathrm{~m}$ in moderately and acutely warmed plots, respectively. This facility can effectively mimic different climatic warming regimes in field in situ, as previously reported (e.g., Hou et al., 2013; Ma et al., 2018; Yu et al., 2018). The watering pulse plots were fully irrigated to field capacity to simulate a watering pulse on 19 August 2014, and 14 August 2017. For the field warming facility, to simulate the shading effects, the control plots were installed with a "dummy" heater similar to those used for the warmed plots. There were a total of 15 experimental plots $(2 \times 2 \mathrm{~m})$ arranged in a $3 \times 5$ matrix with each treatment randomly replicated once in each block across three experimental blocks; a $1 \mathrm{~m}$ buffer for each adjacent plot was made.

\subsection{Soil temperature and moisture}

At the center of each plot, a thermocouple (HOBO S-TMBM006; Onset Computer Corporation, Bourne, MA, USA) was installed at a depth of $5 \mathrm{~cm}$ to measure the soil temperature, and a humidity transducer (HOBO S-SMA-M005; Onset Computer Corporation, Bourne, MA, USA) was installed at a depth of 0 to $20 \mathrm{~cm}$ to monitor the soil moisture $(v / v)$. Continuous half-hour measurements were recorded by an automatic data logger (HOBO H21-002; Onset Computer Corporation, Bourne, MA, USA).

\subsection{Soil respiration}

Soil respiration was measured with a $\mathrm{Li}-8100$ soil $\mathrm{CO}_{2}$ Flux System (LI-COR Inc., Lincoln, NE, USA) with the $R_{\mathrm{S}}$ chamber mounted on polyvinyl chloride (PVC) collars. Fifteen PVC collars ( $10 \mathrm{~cm}$ inside diameter, $5 \mathrm{~cm}$ in height) were inserted into the soil 2 to $3 \mathrm{~cm}$ below the surface. They were randomly placed into the soil in each plot after clipping all plants growing in the collar placement areas. The collars were initially placed a day before measurements were begun to minimize the influence of soil surface disturbance and root injury on $R_{\mathrm{S}}$ (Bao et al., 2010; Wan et al., 2005). Respirations for the control and all of the warmed plots were measured from $06: 00$ to $18: 00 \mathrm{UTC}+8$ on 7 and 8 July and on 18, 19, 20 and 21 August 2014. The $R_{\mathrm{S}}$ for watering pulse treatment was measured after the water additions on $19 \mathrm{Au}$ gust 2014, and 14, 15, 16 and 17 August 2017. To stabilize the measurements, $R_{\mathrm{S}}$ was measured only on selected, typical days (i.e., mildly windy, sunny days). The $R_{\mathrm{S}}$ in all plots was measured once every $2 \mathrm{~h}$ on that day, and each measurement cycle was finished within $30 \mathrm{~min}$ to minimize the effects of environmental variables, such as temperature and light. Thus, a total of six measurement cycles were completed each day. The soil water content (SWC, 0-10 cm soil depth) in watering plots was measured using the Field Scout TDR 300 Soil
Moisture Meter (Spectrum Technologies, Inc., Aurora, IL, USA).

\subsection{Belowground biomass and related soil characteristics}

Soil samples of 0 to $10 \mathrm{~cm}$ in depth were taken from each collar after the $R_{\mathrm{s}}$ measurements and then passed through a $1 \mathrm{~mm}$ sieve to separate the roots. The roots were washed and oven-dried at $70^{\circ} \mathrm{C}$ for $48 \mathrm{~h}$ to a constant weight and then weighed. Subsamples of each soil sample were separated to determine the gravimetrical water content and soil chemical properties. Briefly, to determine the soil organic $\mathrm{C}$ (SOC) content, we mixed a $0.5 \mathrm{~g}$ soil sample, $5 \mathrm{~mL}$ of concentrated sulfuric acid $\left(18.4 \mathrm{~mol} \mathrm{~L}^{-1}\right)$ and $5.0 \mathrm{~mL}$ of aqueous potassium dichromate $\left(\mathrm{K}_{2} \mathrm{Cr}_{2} \mathrm{O}_{7} ; 0.8 \mathrm{~mol} \mathrm{~L}^{-1}\right)$ in a $100 \mathrm{~mL}$ test tube, and then heated them in a paraffin oil pan at $190^{\circ} \mathrm{C}$, keeping them boiling for $5 \mathrm{~min}$. After cooling, the three drops of phenanthroline indicator were added and then the sample was titrated with ferrous ammonium sulfate $\left(0.2 \mathrm{~mol} \mathrm{~L}^{-1}\right)$ until the color of the solution changed from brown to purple to dark green (Nelson and Sommers, 1982; Chen et al., 2008; Edwards and Jfferies, 2013). The soil ammonium-nitrogen $\left(\mathrm{N} ; \mathrm{NH}_{4}^{+}-\mathrm{N}\right)$ concentration and the nitrate- $\mathrm{N}\left(\mathrm{NO}_{3}^{-}-\mathrm{N}\right)$ concentration were extracted with a potassium chloride $(\mathrm{KCl})$ solution and measured using a flow injection analyzer (SEAL Auto Analyzer 3; SEAL Analytical, Inc., Mequon, WI, USA; Liu et al., 2014). Soil samples $(0-10 \mathrm{~cm}$ in depth) from each collar were oven-dried at $105^{\circ} \mathrm{C}$ for at least $48 \mathrm{~h}$ and weighed to determine the SWC. The soil microbial biomass $\mathrm{C}$ (MBC) and microbial biomass $\mathrm{N}(\mathrm{MBN})$ were measured using the chloroform-fumigation extraction method and calculated by subtracting extractable $\mathrm{C}$ and $\mathrm{N}$ contents in the unfumigated samples from those in the fumigated samples (Liu et al., 2014; Rinnan et al., 2009). All extracts were stored at $4{ }^{\circ} \mathrm{C}$ until further testing commenced.

\subsection{Statistical analysis}

All statistical analyses were performed using IBM SPSS Statistics 21.0 (IBM, Armonk, NY, USA). All the data were normal as tested by the Shapiro-Wilk method. A one-way analysis of variation (ANOVA) with LSD multiple range tests was conducted to test the statistical significance of the differences in the mean values of the soil temperature, soil moisture, $R_{\mathrm{S}}$, belowground biomass, $\mathrm{SOC}, \mathrm{NH}_{4}^{+}-\mathrm{N}$ and $\mathrm{NO}_{3}^{-}-\mathrm{N}$ concentrations, and $\mathrm{MBC}$ and $\mathrm{MBN}$ concentrations at depths of 0 to $10 \mathrm{~cm}$ among the different treatments. A linear regression analysis was also used to test the relationship between the SWC and $R_{\mathrm{S}}$. The relationship between $R_{\mathrm{S}}$ and the soil temperature in each treatment was tested with an exponential function. 
We used $Q_{10}$ to express the temperature sensitivity of $R_{\mathrm{S}}$ and calculated it according to the following equations:

$$
\begin{aligned}
& R_{\mathrm{s}}=a e^{b T_{\mathrm{s}}}, \\
& Q_{10}=e^{10 b} .
\end{aligned}
$$

Here, $T_{\mathrm{S}}$ is the soil temperature, $a$ refers to the intercept of $R_{\mathrm{S}}$ when the soil temperature is $0^{\circ}$, and $b$ is the temperature coefficient reflecting the temperature sensitivity of $R_{\mathrm{S}}$ and is used to calculate $Q_{10}$ (Lloyd and Taylor, 1994; Luo et al., 2001; Shen et al., 2015).

The relationship between $R_{\mathrm{S}}$ and the SWC was further conducted to fit the Gompertz function, a sigmoid function (Gompertz, 1825; Yin et al., 2003), which could express that the linear increase is rapid followed by a leveling-off:

$R_{\mathrm{S}}=a \cdot e^{-b \cdot(\exp (-k \cdot \mathrm{SWC}))}$

Here, $a$ is an asymptote; the SWC halfway point of $a / 2$ equals $-\ln (\ln (2) / b) / c$. The turning point of the maximum rate of $R_{\mathrm{s}}$ increase equals $a k / e$ when the SWC equals $\ln (b) / k$. Thus, from the sigmoid function curve, the thresholds of the changes in $R_{\mathrm{S}}$ with increasing SWC can be obtained from the Gompertz function (Gompertz, 1825; Yin et al., 2003).

A non-linear regression model was used to fit the relationship of $R_{\mathrm{S}}$ with both soil temperature and soil moisture (Savage et al., 2009):

$R_{\mathrm{S}}=\left(R_{\mathrm{ref}} \cdot Q_{10}^{\left(T_{\mathrm{S}}-10\right) / 10}\right) \cdot \beta^{\left(\mathrm{SWC}_{0 \mathrm{PT}}-\mathrm{SWC}\right)^{2}}$,

where $T_{\mathrm{S}}$ is the soil temperature at a soil depth of $5 \mathrm{~cm}, R_{\text {ref }}$ is $R_{\mathrm{S}}$ at $10^{\circ} \mathrm{C}$ and $Q_{10}$ is a unitless expression in $R_{\mathrm{S}}$ for each increase in $10^{\circ} \mathrm{C}$. SWC is water content in 0 to $20 \mathrm{~cm}$ soil depth, $\mathrm{SWC}_{0 \mathrm{PT}}$ is the optimal water content and $\beta$ is a parameter modifying the shape of the quadratic fit.

Following the key factors selected by the stepwise regression method, a path analysis was used to examine the primary components directly and indirectly affecting $R_{\mathrm{S}}$ by integrating both the stepwise linear regression module and Pearson correlation analyses (Gefen et al., 2000). The statistical significances were set at $P<0.05$ for all tests, unless otherwise indicated.

\section{Results}

\subsection{Warming effects on belowground characteristics}

The soil temperatures at a soil depth of $5 \mathrm{~cm}$ in the warmed plots were much higher than those in the control plots (Fig. 1). During growing season, the mean soil temperatures in the control, the moderately warmed and acutely warmed plots were $21.9^{\circ} \mathrm{C}( \pm 0.13 \mathrm{SE}), 24.5^{\circ} \mathrm{C}( \pm 0.15)$ and $25.0^{\circ} \mathrm{C}$ $( \pm 0.18)$, respectively. The moderately and acutely warmed plots were respectively increased by $2.6^{\circ} \mathrm{C}(P<0.001)$ and

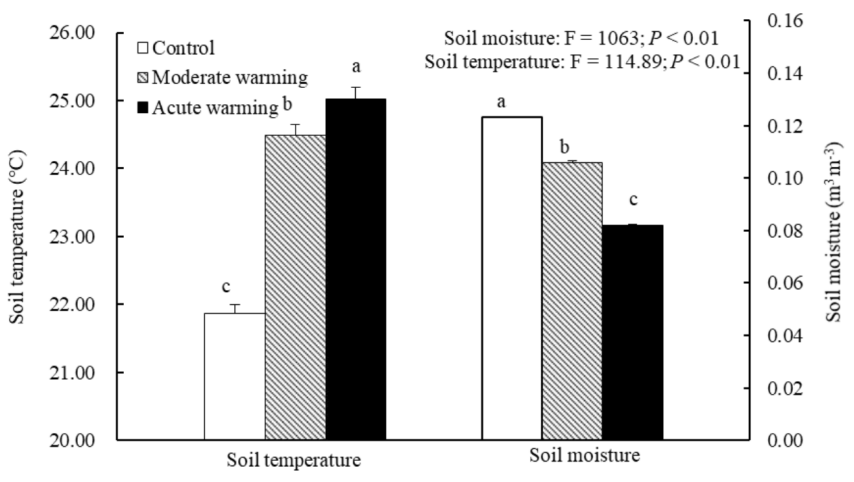

Figure 1. Effects of warming on the soil temperature and soil moisture during the growth peak in 2014 (mean \pm SE). Mean daily values were presented $(n=120)$. The mean values with the same lowercase letters on the SE bars are not different at $P<0.05$ according to LSD multiple range tests ( $P$ values and $F$ ratios are shown inside).

$3.1{ }^{\circ} \mathrm{C}(P<0.001)$ compared to those in the control plots. The SWC in the moderately and acutely warmed plots $(0$ $20 \mathrm{~cm}$ soil profile, defined as ratios of water volume and soil volume) were significantly reduced $(P<0.001)$ compared to those in the control plots (Fig. 1), indicating that warming led to marked declines in the SWC, consequently enhancing drought stress. On 18, 19, 20 and 21 August, which were the dates that we measured $R_{\mathrm{S}}$, the daily soil temperatures in the moderately and acutely warmed plots were around 3 and $4{ }^{\circ} \mathrm{C}$ higher than those in the control plots, respectively. All belowground variables (belowground biomass, soil $\mathrm{N}$ and microbial characteristics) were not significantly altered by warming regimes at the site of this experiment (Table S1 in the Supplement; $P>0.05)$. However, the organic soil carbon content tended to decrease with long-term climatic warming.

\subsection{Watering pulse effects on $\boldsymbol{R}_{\mathrm{S}}$}

Soil respiration significantly increased with SWC both linearly $\left(R^{2}=0.83 ; P<0.01\right)$ and quadratically $\left(R^{2}=\right.$ $0.88 ; P<0.01$, Fig. 2a). Moreover, the Gompertz function was well fitted to their relationship $\left(R^{2}=0.87\right.$; RMSE $=4.88$; Fig. 2b). From the Gompertz functional curve, the $R_{\mathrm{S}}$ asymptote value, as an estimated maximum, was $3.76 \mu \mathrm{mol} \mathrm{m} \mathrm{m}^{-2} \mathrm{~s}^{-1}$ when the optimal SWC was $22.85 \%$. In the watering plots, an exponential function was well fitted to the relationship between soil respiration and the soil temperatures $\left(R^{2}=0.31 ; P<0.01\right)$, with a temperature sensitivity $\left(Q_{10}\right)$ of 1.70 . However, the exponential function was not well fitted in the control plots (Fig. 3a).

\subsection{Effects of warming regimes on $\boldsymbol{R}_{\mathrm{s}}$}

Warming regimes resulted in marked declines in $R_{\mathrm{S}}$. Whereas no difference in $R_{\mathrm{S}}$ was observed in July, during August average $R_{\mathrm{S}}$ values were $1.57,1.06$ and $0.93 \mu \mathrm{mol} \mathrm{m}{ }^{-2} \mathrm{~s}^{-1}$ in 

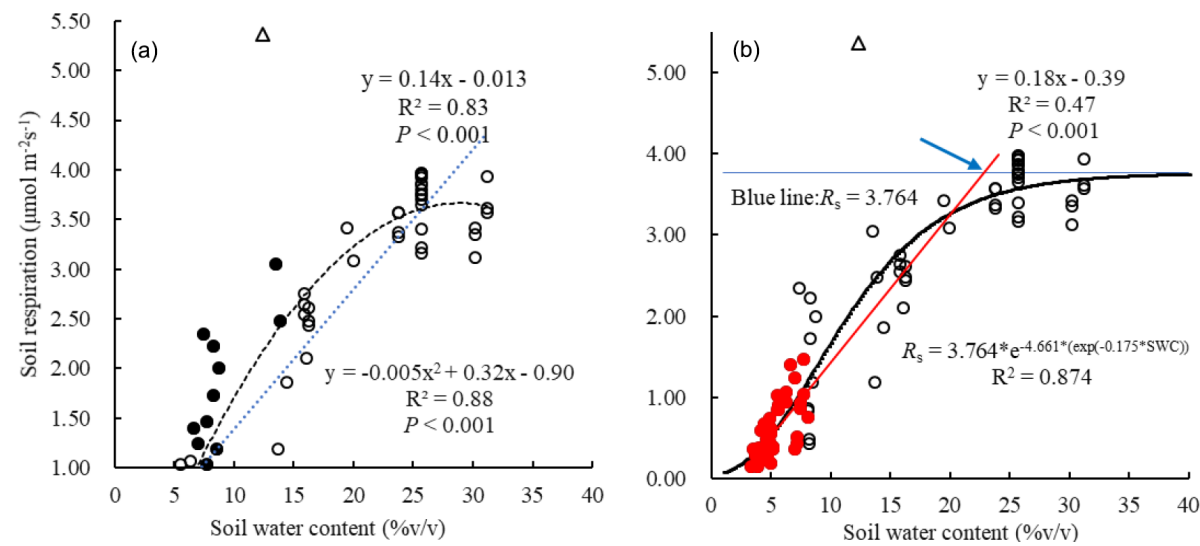

Figure 2. Relationship between $R_{\mathrm{S}}$ and soil water content based on a linear (blue line) and a quadratic (black line) functional model (a), and Gompertz functional model (b). Close and open circles denote the data in 2014 and 2017, respectively. The close red circles indicate data used for the linear $R_{\mathrm{S}}$ response to SWC at low levels. The one open triangle may be an outlier point due to some errors, but it does not notably affect the functional fitting when removing it (ref. Fig. S2). Based on Gompertz functional curve, the $R_{\mathrm{S}}$ asymptote value, as an estimated maximum, is $3.76 \mu \mathrm{mol} \mathrm{m} \mathrm{m}^{-2} \mathrm{~s}^{-1}$ when the optimal SWC is $22.85 \%$ (the red line denotes the initial $R_{\mathrm{S}}$ response to SWC; the blue line denotes $R_{\mathrm{S}}=$ constant value of the maximum estimated by the asymptote value; and the intersection of the two lines represents a point (the blue arrow) at which $R_{\mathrm{S}}$ leveled off). Note that we measured the $R_{\mathrm{S}}$ from 06:00 to 18:00 on these cloudless days with calm/gentle wind in order to keep other environmental factors such as soil temperature and radiation relatively stable and constant. The data were collected in the plots of watering treatments $(n=92)$.
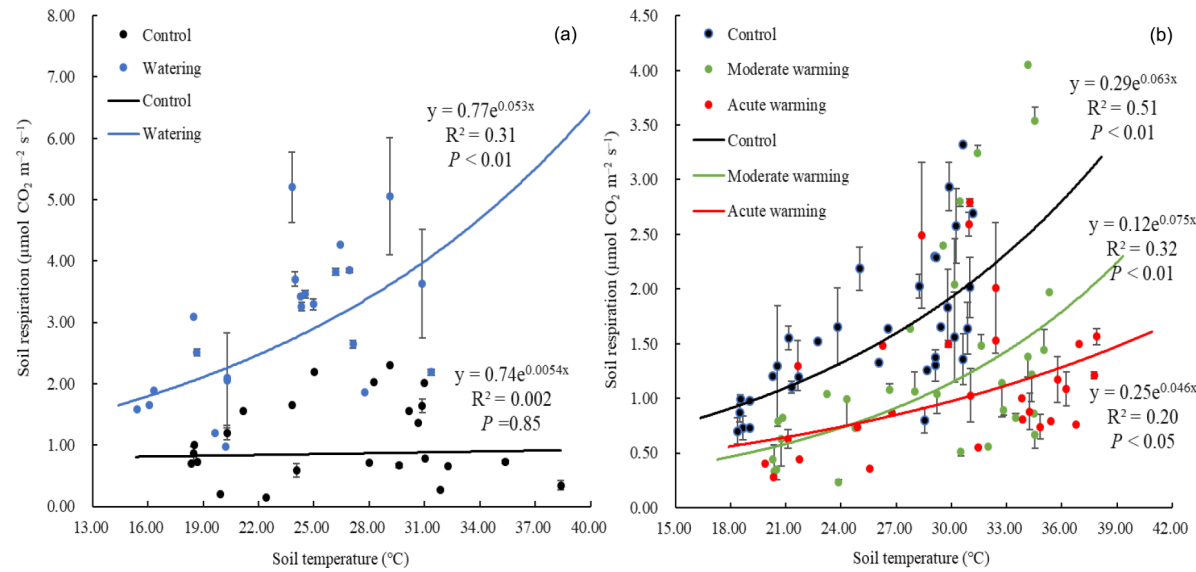

Figure 3. The relationships between soil respiration and soil temperature under both watering $(n=23-25$, mean $\pm \mathrm{SE}$; a) and warming treatments $(n=28-33$, mean $\pm \mathrm{SE} ; \mathbf{b})$.

the control, moderately warmed and acutely warmed plots, respectively, indicating that warming regimes resulted in marked declines (Fig. 4). Changes in $R_{\mathrm{S}}$ differed significantly between the control and both warmed plots $(P<$ $0.01)$, while the $R_{\mathrm{S}}$ in the two warmed plots did not significantly differ from each other $(P=0.45)$. The relationships between the $R_{\mathrm{S}}$ and soil temperature of each treatment were well fitted by the exponential equations $(P<0.05$; Fig. 3b). The $Q_{10}$ values were $1.88,2.12$ and 1.58 in the temperature-controlled, moderate warming and acute warming treatments, respectively (Fig. 3b). It indicated that $R_{\mathrm{S}}$ increased exponentially with temperature in watered plots but was lower and insensitive to temperature in the control plots
(Fig. 3a), and that long-term warming rather than temporary high temperature reduced $R_{\mathrm{s}}$, despite having a positive relationship with soil temperature (Figs. 3b, 4).

\subsection{Interactive effects on $\boldsymbol{R}_{\mathrm{S}}$ from soil temperature and soil water content}

Across all watering and warming treatments, generally, high temperature led to an increase in $R_{\mathrm{S}}$ under ample soil moisture, whereas $R_{\mathrm{S}}$ was limited under a soil water deficit. As shown in Fig. 5, a non-linear regression model (Eq. 4) was well fitted to the relationship of $R_{\mathrm{S}}$ with both soil temperature and soil moisture in the control plots $\left(R^{2}=\right.$ $0.40, \mathrm{RMSE}=0.60)$. Based on the function $R_{\mathrm{S}}=(0.733$. 


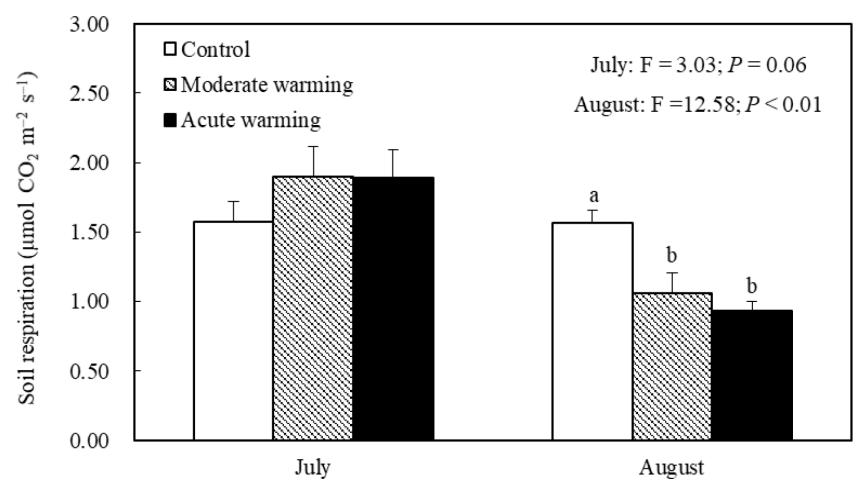

Figure 4. Effects of warming regimes on average soil respiration in 2014 (mean $\pm \mathrm{SE}$ ); the mean values with the same lowercase letters on the SE bars are not different at $P<0.05$ according to LSD multiple range tests ( $P$ values and $F$ ratios are shown inside).

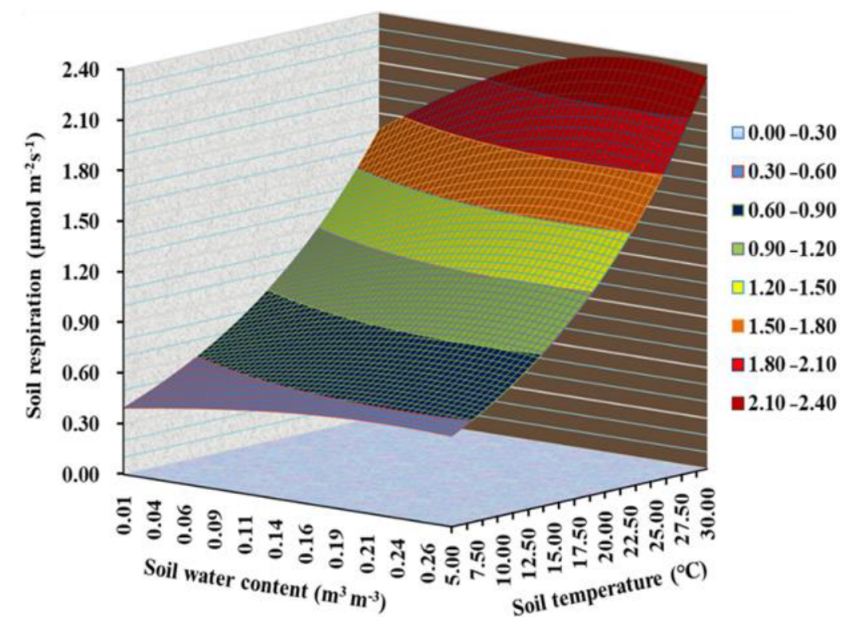

Figure 5. An interactive relationship of soil respiration with both soil temperature $\left(T_{\mathrm{S}}\right)$ and soil water content (SWC) based on a nonlinear mixed model $\left(R_{\mathrm{S}}=\left(0.733 \cdot 1.796^{\left(T_{\mathrm{S}}-10\right) / 10}\right)\right.$. $\left.\beta^{(0.229-\mathrm{SWC})^{2}}\right)$. The data were used in control plots in the warming experiment. The optimal SWC of 0.229 was estimated by the Gompertz functional curve (see Fig. 2b).

$\left.1.796^{\left(T_{\mathrm{S}}-10\right) / 10}\right) \cdot \beta^{(0.229-\mathrm{SWC})^{2}}$, the key parameters were obtained: $R_{\text {ref }}, R_{\mathrm{S}}$ at $10^{\circ} \mathrm{C}$, was $0.73 \mu \mathrm{mol} \mathrm{m}{ }^{-2} \mathrm{~s}^{-1} ; Q_{10}$, a unitless expression in $R_{\mathrm{S}}$ for each increase in $10^{\circ} \mathrm{C}$, was 1.80 ; and $\beta$, a parameter modifying the shape of the quadratic fit, was 0.001 (Fig. 5).

\subsection{Effects of multiple factors on $\boldsymbol{R}_{\mathrm{s}}$ : a path analysis}

Based on a stepwise regression analysis of the relationships between the $R_{\mathrm{S}}$ and multiple factors, four key factors were screened: soil temperature, soil moisture, belowground biomass and SOC. Their effects on $R_{\mathrm{S}}$ were further determined by path analysis. The results showed that soil moisture and soil temperature were two major direct factors controlling $R_{\mathrm{S}}$ (the two direct path coefficients were 0.72 and 0.55 ,

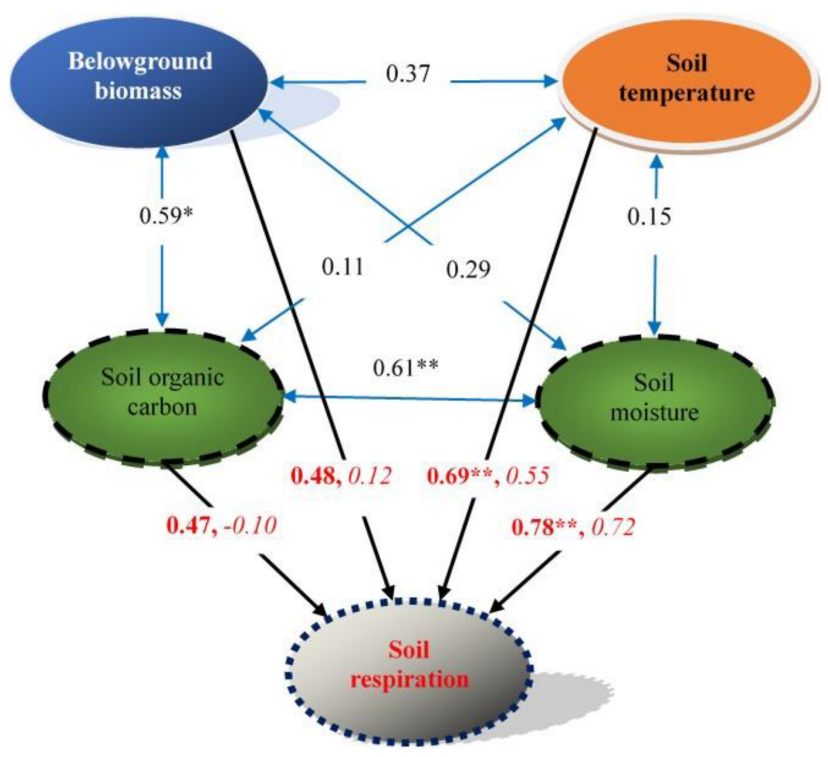

Figure 6. A diagram of the effects of key environmental factors on soil respiration and their relationships. Blue double-headed arrows represent the relationships between the key environmental factors; data on the arrows are correlation coefficients. Black arrows represent the relationships between soil respiration and the key environmental factors; data on the arrows are correlation coefficients (bold) and direct path coefficients (italic), respectively. ${ }^{*} P<0.05$; ** $P<0.01, n=12$. For other details, see Table S2.

respectively). SOC had the highest indirect effect on $R_{\mathrm{S}}$ (the indirect path coefficient was 0.57 ). Soil moisture highly correlated with $R_{\mathrm{S}}(R=0.78, P<0.01$; Table S2, Fig. 6), indicating again that the soil water status may impose the greatest effect on the carbon release from soil in the desert grassland.

\section{Discussion}

\subsection{Warming effects on $R_{\mathrm{S}}$}

Previous studies have shown positive $R_{\mathrm{S}}$ responses to increased soil temperatures below a critical high temperature (e.g., Carey et al., 2016; Drewitt et al., 2002; Gaumont-Guay et al., 2006; Meyer et al., 2018). However, in the current study site, the climatic warming finally reduced the average $R_{\mathrm{S}}$ by $32.5 \%$ and $40.8 \%$ under long-term versus shortterm climatic warming conditions in the desert dryland, respectively, which chiefly confirmed our first hypothesis. In a semiarid grassland on the Loess Plateau of China, the total $R_{\mathrm{S}}$ was also constrained substantially by a field manipulative experiment (Fang et al., 2018). This result may have been caused by the following factors. First, high temperatures may cause thermal stress on microbes and subsequently reduce microbial respiration (i.e., heterotrophic, $R_{\mathrm{h}}$, Chang et al., 2012; Dacal et al., 2019). For instance, in an alpine steppe on the Tibetan Plateau, microbial respiration was significantly 
reduced when the temperature rose to $30^{\circ} \mathrm{C}$ (Chang et al., 2012). Second, in the desert grassland, where water is often limited, the SWC becomes the primary factor affecting $R_{\mathrm{S}}$ (Table S2; Fig. 6), while warming can cause greater evapotranspiration, consequently lessening soil moisture (Fig. 1), and finally reducing $R_{\mathrm{S}}$ (Munson et al., 2009; Wan et al., 2007; Yan et al., 2013). The decreases in average $R_{\mathrm{S}}$ with warming implicate that the positive feedback loop could be weakened with increasing length or intensity of warming.

Total respiration $\left(R_{\mathrm{s}}\right.$; the sum of root (autotrophic, $R_{\mathrm{a}}$ ) and $R_{\mathrm{h}}$ respiration - the former accounting for ca. $22 \%$ of the total $R_{\mathrm{S}}$ in the ecosystem; T. Liu et al., 2016) may acclimatize to warming within an appropriate range of temperature change at an ample soil moisture; however, it decreases with increasing temperatures above an optimum level. The mechanisms may be the following: within an appropriate range of temperature change at an ample soil moisture, climatic warming can enhance both plant root (Luo et al., 2001; T. Liu et al., 2016) and microbial activities (Tucker et al., 2013), leading to increases in both $R_{\mathrm{a}}$ and $R_{\mathrm{h}}$, and consequently the $R_{\mathrm{S}}$ (Luo et al., 2001; Tucker and Reed, 2016; Xu et al., 2019). However, when warming continues or with increasing temperatures above an optimum level, root growth can be constrained, directly reducing $R_{\mathrm{a}}$ (Carey et al., 2016; T. Liu et al., 2016; Luo et al., 2001; Moncrieff et al., 1999; Wan et al., 2007); limitation to microbial activities may also occur (Tucker et al., 2013; Yu et al., 2018), decreasing the $R_{\mathrm{h}}$ (Bérard et al., 2011, 2015; Tucker et al., 2013; RomeroOlivares et al., 2017). In addition, decreases in soil enzyme pools and their activity under warming may also contribute to a reduction in $R_{\mathrm{h}}$ (e.g., Alvarez et al., 2018). Further, $R_{\mathrm{S}}$ decreases with warming under a water deficit (Moyano et al., 2013; Wang et al., 2014; and see below). Together, the declines in both root and microbial respirations finally reduce the $R_{\mathrm{S}}$. Nevertheless, the drastic declines in $R_{\mathrm{S}}$ under both long- and short-term climatic warming regimes in the desert dryland ecosystem may be driven by multiple factors, including the ecosystem type, time and soil features (T. Liu et al., 2016; Wan et al., 2007; Meyer et al., 2018; Thakur et al., 2019). It implies that the effects of multiple factors should be considered in assessing the carbon balance between ecosystem and atmosphere.

\subsection{Interactive effect of soil water status and temperature}

As stated above, in an arid ecosystem, soil water deficit is a primary factor inhibiting soil carbon release (Table S2; Fig. 6; T. Liu et al., 2016; Munson et al., 2009; Yan et al., 2013). Thus, $R_{\mathrm{S}}$ linearly increases with increasing soil moisture. However, it could be leveled off or decreased when soil moisture exceeds an optimal level for the soil carbon release (Huxman et al., 2004; Moyano et al., 2013; Wang et al., 2014). Thus, the relationship between $R_{\mathrm{S}}$ and SWC may be well fitted to the Gompertz functional curve model, a sig- moid function (Gompertz, 1825; Yin et al., 2003), which can be confirmed by the present results in the native arid desert ecosystem (Fig. 2b). The mechanisms mainly are that an increase in SWC may rapidly increase microbial activities $(\mathrm{Ca}-$ ble et al., 2008; Meisner et al., 2015; Wu and Lee, 2011), and enhance root growth (Xu et al., 2014), leading to a linear increase in $R_{\mathrm{S}}$. However, when soil moisture reaches an ample level, microbial activities may also reach a maximum, where the limiting effects of substrate occur (Skopp et al., 1990), finally maintaining a stable change in $R_{\mathrm{h}}$. A similar response to watering appears for root growth (Xu et al., 2014), and also similarly leading to a stable change in $R_{\mathrm{a}}$. Thus, $R_{\mathrm{S}}$ can be leveled off at an increased and stable level. Moreover, the decrease in $R_{\mathrm{S}}$ at a saturated SWC level may be ascribed to inhibitions of both root systems and microbial activities under the anaerobic environment (Drew, 1997; Huxman et al., 2004; Kwon et al., 2019; Sánchez-Rodríguez et al., 2019; Yan et al., 2018). The model concerning the relationship $R_{\mathrm{S}}$ with a broad range of SWC is helpful to assess and predict the dynamics in soil carbon release in natural arid ecosystems.

As indicated by Tucker and Reed (2016), soil water deficit can shrink the $R_{\mathrm{S}}$ itself and its response to temperature, suggesting that the changes in $R_{\mathrm{S}}$ may be determined simultaneously by both soil temperature and water status (Janssens et al., 2001; Yan et al., 2013; Sierra et al., 2015). Moreover, in the present experiment, the interactive effects of both factors were tested based on the relationship of $R_{\mathrm{S}}$ with both soil temperature and soil moisture in a non-linear regression model (Savage et al., 2009). The model utilized was well fitted but marginally so $\left(R^{2}=0.40, \mathrm{RMSE}=0.596\right.$; Fig. 5), indicating that both the soil temperature and SWC coordinated the changes in $R_{\mathrm{s}}$. However, this interaction may also be affected simultaneously by other abiotic and biotic factors, such as soil nutrition availability and soil microbe activity (e.g., Camenzind et al., 2018; Han et al., 2006; Karhu et al., 2014; Thakur et al., 2019; Zhang et al., 2014).

\subsection{Key factors and the influence path}

As noted above, $R_{\mathrm{S}}$ is affected by several abiotic and biotic factors. The current results showed that soil moisture and soil temperature were two major direct factors, and SOC was only an indirect factor controlling $R_{\mathrm{S}}$ (Table S2, Fig. 6). Importantly, soil moisture, with both the highest direct path coefficients $(0.7)$ and correlation coefficient $(0.8)$ for $R_{\mathrm{S}}$, may become the most important factor affecting $R_{\mathrm{S}}$ in this desert steppe. These findings agree with the previous results: improved soil water status had a significantly positive effect on $R_{\mathrm{S}}$ (e.g., Chen et al., 2008; T. Liu et al., 2016; Xu et al., 2016). Furthermore, soil moisture conditions can mediate the relationship between soil temperature and $R_{\mathrm{S}}$, thus affecting $R_{\mathrm{S}}$ temperature sensitivity; SWC becomes the main factor controlling $R_{\mathrm{s}}$, especially in arid ecosystems, such as desert steppes, where the available soil water is limited (Conant et al., 2000; Curiel et al., 2003; Fa et al., 2018; Jassal et al., 
2008; Roby et al., 2019). Thus, under both the long- and short-term climatic warming regimes, soil moisture could modulate the response of $R_{\mathrm{S}}$ to warming. The changes in $R_{\mathrm{S}}$ might be driven by both soil temperature and soil moisture as two key factors, and SOC as an indirect factor, thus mostly confirming our second hypothesis. The findings again implicate that multiple factors together coordinate $R_{\mathrm{S}}$, and provide new insight into how to control soil carbon release in arid ecosystems. The models on the $R_{\mathrm{S}}$ changes should consider multiple-factor effects of soil carbon dynamics when assessing and predicting carbon cycle, and its climate feedback.

\subsection{Warming effects on the variables belowground}

Elevated temperature has been shown to increase or decrease root productivity and biomass, depending on experimental sites and vegetation types (Bai et al., 2010; Fan et al., 2009; Litton and Giardina, 2008; Wan et al., 2004). The decreased availability of soil nutrients apparently limits root growth, finally inducing root mortality and weakening responses to the elevated temperature (Eissenstat et al., 2000; Johnson et al., 2006; Wan et al., 2004; Zhang et al., 2014). In our experiment, no significantly different changes occurred in either soil $\mathrm{NH}_{4}^{+}-\mathrm{N}$ or $\mathrm{NO}_{3}^{-}-\mathrm{N}$ concentrations among the three treatments (Table S1), and these might be linked to the nonsignificant response of belowground biomass to increasing temperature. Microbial biomass and its activities in soil depend on the root biomass, SWC and soil N conditions (Liu et al., 2014; Rinnan et al., 2007; Zhang et al., 2008, 2014). Warming regimes had no significant effects on either MBC or MBN in the current study (Table S1), which might be due to the lack of any difference in the changes in basic soil nutrition status, such as the $\mathrm{N}$ conditions, among the three warming treatments. This result is consistent with those of Zhang et al. (2005) and Liu et al. (2015). Moreover, in the present study, SOC concentrations were not significantly affected by climatic warming (Table S1), which is inconsistent with the findings of previous studies (Jobbágy and Jackson, 2000; Prietzel et al., 2016). However, there might be a decreasing trend evident with long-term warming. For instance, Crowther et al. (2016) reported a loss of approximately $30 \pm 30 \mathrm{Pg}$ of C in the upper soil horizons at $1{ }^{\circ} \mathrm{C}$ warming in global soil $\mathrm{C}$ stocks and projected a loss of $203 \pm 161 \mathrm{Pg}$ of $\mathrm{C}$ under $1{ }^{\circ} \mathrm{C}$ of warming over 35 years. The $\mathrm{C}$ losses from soil moving into the atmosphere may result in positive feedback regarding global warming (Bradford et al., 2016; Dacal et al., 2019; Jenkinson et al., 1991; T. Liu et al., 2016; Martins et al., 2016). However, SOC was shown to have exerted an indirect effect via path analysis (Fig. 6). For this difference, therefore, more evidence needs to be provided to address the issue (Xu et al., 2019).

In conclusion, we determined the responses of $R_{\mathrm{S}}$ to field experimental long- versus short-term climatic warming and watering pulses in a desert steppe ecosystem. We found the following: (i) both long- and short-term warming signifi- cantly reduced $R_{\mathrm{S}}$ during the peak growth season; (ii) soil moisture was the main factor controlling $R_{\mathrm{S}}$ in desert grassland; (iii) $R_{\mathrm{S}}$ was significantly and exponentially increased with soil temperature, while soil moisture conditions can mediate the relationship between soil temperature and $R_{\mathrm{s}}$, thus affecting its temperature sensitivity; and (iv) belowground biomass, soil nutrition variables and soil microbial characteristics showed no significant changes after either long-term or short-term climatic warming. These findings may be useful in assessing and predicting the dynamics of soil $\mathrm{CO}_{2}$ fluxes, particularly the feedback of warming to climatic change, and finally optimizing $\mathrm{C}$ management work in arid and semiarid regions under the changing climate. However, the patterns of the changes in soil C fluxes and the underlying mechanism in response to climatic change are markedly complicated at various spatial-temporal scales during the growing season - from site and regional to global scales, and from daily, seasonal and yearly to decade scales - and still need to be investigated further (e.g., Ballantyne et al., 2017; Dacal et al., 2019; Meyer et al., 2018; Romero-Olivares et al., 2017).

Data availability. The final derived data presented in this study are available at https://doi.org/10.5281/zenodo.3546062 (Yu et al., 2019).

Supplement. The supplement related to this article is available online at: https://doi.org/10.5194/bg-17-781-2020-supplement.

Author contributions. ZX and GZ conceived and designed this study. HY, ZX and YS conducted this experiment and analyzed the data. All authors wrote and proofread this manuscript.

Competing interests. The authors declare that they have no conflict of interest.

Acknowledgements. We greatly thank Feng Zhang, Yuhui Wang, Bingrui Jia, Hui Wang, Minzheng Wang and He Song for their loyal help during the present study. The authors also greatly appreciate Martin De Kauwe and the four anonymous reviewers for their constructive comments.

Financial support. This research has been supported by the National Natural Science Foundation of China (grant nos. 31661143028 and 41775108) and China Special Fund for Meteorological Scientific Research in the Public Interest (Major projects) (grant no. GYHY201506001-3).

Review statement. This paper was edited by Martin De Kauwe and reviewed by four anonymous referees. 


\section{References}

Alvarez, G., Shahzad, T., Andanson, L., Bahn, M., Wallenstein, M. D., and Fontaine, S.: Catalytic power of enzymes decreases with temperature: New insights for understanding soil C cycling and microbial ecology under warming, Glob. Change Biol., 24, 4238-4250, https://doi.org/10.1111/gcb.14281, 2018.

Bai, W., Wan, S., Niu, S., Liu, W., Chen, Q., Wang, Q., Zhang, W., Han, X., and Li, L.: Increased temperature and precipitation interact to affect root production, mortality, and turnover in a temperate steppe: implications for ecosystem C cycling, Glob. Change Biol., 16, 1306-1316, https://doi.org/10.1111/j.13652486.2009.02019.x, 2010.

Ballantyne, A., Smith, W., Anderegg, W., Kauppi, P., Sarmiento, J., Tans, P., Shevliakova, E., Pan, Y., Poulter, B., Anav, A., and Friedlingstein, P.: Accelerating net terrestrial carbon uptake during the warming hiatus due to reduced respiration, Nat. Clim. Change, 7, 148-152, https://doi.org/10.1038/nclimate3204, 2017

Bao, F., Zhou, G. S., Wang, F. Y., and Sui, X. H.: Partitioning soil respiration in a temperate desert steppe in Inner Mongolia using exponential regression method, Soil Biol. Biochem., 42, 23392341, https://doi.org/10.1016/j.soilbio.2010.08.033, 2010.

Bérard, A., Bouchet, T., Sévenier, G., Pablo, A. L., and Gros, R.: Resilience of soil microbial communities impacted by severe drought and high temperature in the context of Mediterranean heat waves, Eur. J. Soil Biol., 47, 333-342, https://doi.org/10.1016/j.ejsobi.2011.08.004, 2011.

Bérard, A., Sassi, M. B., Kaisermann, A., and Renault, P.: Soil microbial community responses to heat wave components: drought and high temperature, Clim. Res., 66, 243-264, https://doi.org/10.3354/cr01343, 2015.

Boone, R. D., Nadelhoffer, K. J., Canary, J. D., and Kaye, J. P.: Roots exert a strong influence on the temperature sensitivity of soil respiration, Nature, 396, 570-572, https://doi.org/10.1038/25119, 1998.

Bradford, M. A., Wieder, W. R., Bonan, G. B., Fierer, N., Raymond, P. A., and Crowther, T. W.: Managing uncertainty in soil carbon feedbacks to climate change, Nat. Clim. Change, 6, 751-758, https://doi.org/10.1038/nclimate3071, 2016.

Cable, J. M., Ogle, K., Williams, D. G., Weltzin, J. F., and Huxman, T. E.: Soil texture drives responses of soil respiration to precipitation pulses in the Sonoran Desert: Implications for climate change, Ecosystems, 11, 961-979, https://doi.org/10.1007/s10021-008-9172-x, 2008.

Camenzind, T., Hättenschwiler, S., Treseder, K. K., Lehmann, A., and Rillig, M. C.: Nutrient limitation of soil microbial processes in tropical forests, Ecol., Monogr., 88, 4-21, https://doi.org/10.1002/ecm.1279, 2018.

Carey, J. C., Tang, J., Templer, P. H., Kroeger, K. D., Crowther, T. W., Burton, A. J., Dukes, J. S., Emmett, B., Frey, S. D., Heskel, M. A., and Jiang, L.: Temperature response of soil respiration largely unaltered with experimental warming, P. Natl. Acad. Sci. USA, 113, 13797-13802, https://doi.org/10.1073/pnas.1605365113, 2016.

Chang, X., Wang, S., Luo, C., Zhang, Z., Duan, J., Zhu, X., Lin, Q., and $\mathrm{Xu}, \mathrm{B}$.: Responses of soil microbial respiration to thermal stress in alpine steppe on the Tibetan plateau, Eur. J. Soil Sci., 63, 325-331, https://doi.org/10.1111/j.1365-2389.2012.01441.x, 2012.
Chen, S. P., Lin, G. H., Huang, J. H., and He, M.: Responses of soil respiration to simulated precipitation pulses in semiarid steppe under different grazing regimes, J. Plant Ecol., 1, 237246, https://doi.org/10.1093/jpe/rtn020, 2008.

Conant, R. T., Klopatek, J. M., and Klopatek, C. C.: Environmental factors controlling soil respiration in three semiarid ecosystems, Soil Sci. Soc. Am. J., 64, 383-390, https://doi.org/10.2136/sssaj2000.641383x, 2000.

Crowther, T. W., Todd-Brown, K. E., Rowe, C. W., Wieder, W. R., Carey, J. C., Machmuller, M. B., Snoek, B. L., Fang, S., Zhou, G., Allison, S. D., and Blair, J. M.: Quantifying global soil carbon losses in response to warming, Nature, 540, 104-108, https://doi.org/10.1038/nature20150, 2016.

Curiel, J. C., Janssens, I. A, Carrara, A., Meiresonne, L., and Ceulemans, R.: Interactive effects of temperature and precipitation on soil respiration in a temperate maritime pine forest, Tree Physiol., 23, 1263-1270, https://doi.org/10.1093/treephys/23.18.1263, 2003.

Dacal, M., Bradford, M. A., Plaza, C., Maestre, F. T., and GarcíaPalacios, P.: Soil microbial respiration adapts to ambient temperature in global drylands, Nat. Ecol. Evol., 3, 232-238, https://doi.org/10.1038/s41559-018-0770-5, 2019.

Drew, M. C.: Oxygen deficiency and root metabolism: injury and acclimation under hypoxia and anoxia, Annu. Rev. Plant Biol., 48, 223-250, https://doi.org/10.1146/annurev.arplant.48.1.223, 1997.

Drewitt, G. B., Black, T. A., Nesic, Z., Humphreys, E. R., Jork, E. M., Swanson, R., Ethier, G. J., Griffis, T., and Morgenstern, K.: Measuring forest floor $\mathrm{CO}_{2}$ fluxes in a Douglas-fir forest, Agr. Forest Meteorol., 110, 299-317, https://doi.org/10.1016/S01681923(01)00294-5, 2002.

Edwards, K. A. and Jfferies, R. L.: Inter-annual and seasonal dynamics of soil microbial biomass and nutrients in wet and dry low-Arctic sedge meadows, Soil Biol. Biochem., 57, 83-90, https://doi.org/10.1016/j.soilbio.2012.07.018, 2013.

Eissenstat, D. M., Wells, C. E., Yanai, R. D., and Whitbeck, J. L.: Research view: Building roots in a changing environment: Implications for root longevity, New Phytol., 147, 33-42, 2000.

Fa, K., Zhang, Y., Lei, G., Wu, B., Qin, S., Liu, J., Feng, W., and Lai, Z.: Underestimation of soil respiration in a desert ecosystem, Catena, 162, 23-28, https://doi.org/10.1016/j.catena.2017.11.019, 2018.

Falkowski, P., Scholes, R. J., Boyle, E. E. A., Canadell, J., Canfield, D., Elser, J., Gruber, N., Hibbard, K., Högberg, P., Linder, S., and Mackenzie, F. T.: The global carbon cycle: a test of our knowledge of earth as a system, Science, 290, 291-296, https://doi.org/10.1126/science.290.5490.291, 2000.

Fan, J. W., Wang, K., Harris, W., Zhong, H. P., Hu, Z. M., Han, B., Zhang, W. Y., and Wang, J. B.: Allocation of vegetation biomass across a climate-related gradient in the grasslands of Inner Mongolia, J. Arid Environ., 73, 521-528, https://doi.org/10.1016/j.jaridenv.2008.12.004, 2009.

Fang, C., Li, F., Pei, J., Ren, J., Gong, Y., Yuan, Z., Ke, W., Zheng, Y., Bai, X., and Ye, J. S.: Impacts of warming and nitrogen addition on soil autotrophic and heterotrophic respiration in a semi-arid environment, Agr. Forest Meteorol., 248, 449-457, https://doi.org/10.1016/j.agrformet.2017.10.032, 2018.

Gaumont-Guay, D., Black, T. A., Griffis, T. J., Barr, A. G., Jassal, R. S., and Nesic, Z.: Interpreting the dependence of 
soil respiration on soil temperature and water content in a boreal aspen stand, Agr. Forest Meteorol., 140, 220-235, https://doi.org/10.1016/j.agrformet.2006.08.003, 2006.

Gefen, D., Straub, D., and Boudreau, M. C.: Structural equation modelling and regression: Guidelines for research practice, Communications of the Association for Information Systems, 4, 7, https://doi.org/10.17705/1CAIS.00407, 2000.

Gompertz, B.: On the nature of the function expressive of the law of human mortality, and on a new mode of determining the value of life contingencies, Philos. T. R. Soc. Lond., 115, 513-583, https://doi.org/10.1098/rstl.1825.0026, 1825.

Han, G. X., Zhou, G. S., Xu, Z. Z., Yang, Y., Liu, J. L., and Shi, K. Q.: Soil temperature and biotic factors drive the seasonal variation of soil respiration in a maize (Zea mays L.) agricultural ecosystem, Plant Soil, 291, 15-26, https://doi.org/10.1007/s11104-006-9170-8, 2006.

Hoover, D. L., Knapp, A. K., and Smith, M. D.: The immediate and prolonged effects of climate extremes on soil respiration in a mesic grassland, J. Geophys. Res.-Biogeo., 121, 1034-1044, https://doi.org/10.1002/2015JG003256, 2016.

Hou, Y. H., Zhou, G. S., Xu, Z. Z., Liu, T., and Zhang, $X$. S.: Interactive effects of warming and increased precipitation on community structure and composition in an annual forb dominated desert steppe, PLoS one, 8, e70114, https://doi.org/10.1371/journal.pone.0070114, 2013.

Huxman, T. E., Snyder, K. A., Tissue, D., Leffler, A. J., Ogle, K., Pockman, W. T., Sandquist, D. R., Potts, D. L., and Schwinning, S.: Precipitation pulses and carbon fluxes in semiarid and arid ecosystems, Oecologia, 141, 254-268, https://doi.org/10.1007/s00442-004-1682-4, 2004.

IPCC: Climate Change 2014: Synthesis Report. Contribution of Working Groups I, II and III to the Fifth Assessment Report of the Intergovernmental Panel on Climate Change, edited by: Core Writing Team, Pachauri, R. K., and Meyer, L. A., IPCC, Geneva, Switzerland, 151 pp., 2014.

IPCC: Climate Change and Land: an IPCC special report on climate change, desertification, land degradation, sustainable land management, food security, and greenhouse gas fluxes in terrestrial ecosystems, edited by: Shukla, P. R., Skea, J., Calvo Buendia, E., Masson-Delmotte, V., Pörtner, H.-O., Roberts, D. C., Zhai, P., Slade, R., Connors, S., van Diemen, R., Ferrat, M., Haughey, E., Luz, S., Neogi, S., Pathak, M., Petzold, J., Portugal Pereira, J., Vyas, P., Huntley, E., Kissick, K., Belkacemi, M., and Malley, J., IPCC, available at: https://www.ipcc.ch/report/srccl/ (last access: 12 February 2020), 2019.

Janssens, I. A., Kowalski, A. S., and Ceulemans, R.: Forest floor $\mathrm{CO}_{2}$ fluxes estimated by eddy covariance and chamber-based model, Agr. Forest Meteorol., 106, 61-69, https://doi.org/10.1016/S0168-1923(00)00177-5, 2001.

Jassal, R. S., Black, T. A., Novak, M. D., Gaumont-Guay, D., and Nesic, Z.: Effect of soil water stress on soil respiration and its temperature sensitivity in an 18-year-old temperate Douglas-fir stand, Glob. Change Biol., 14, 1-14, https://doi.org/10.1111/j.1365-2486.2008.01573.x, 2008.

Jenkinson, D. S., Adams, D. E., and Wild, A.: Model estimates of $\mathrm{CO}_{2}$ emissions from soil in response to global warming, Nature, 351, 304-306, https://doi.org/10.1038/351304a0, 1991.

Jia, B., Zhou, G., Wang, Y., Wang, F., and Wang, X.: Effects of temperature and soil water-content on soil respiration of grazed and ungrazed Leymus chinensis steppes, Inner Mongolia, J. Arid Environ., 67, 60-76, https://doi.org/10.1016/j.jaridenv.2006.02.002, 2006.

Jobbágy, E. G. and Jackson, R. B.: The vertical distribution of soil organic carbon and its relation to climate and vegetation, Ecol. Appl., 10, 423-436, https://doi.org/10.1890/10510761(2000)010[0423:TVDOSO]2.0.CO;2, 2000.

Johnson, M. G., Rygiewicz, P. T., Tingey, D. T., and Phillips, D. L.: Elevated $\mathrm{CO}_{2}$ and elevated temperature have no effect on Douglas-fir fine-root dynamics in nitrogen-poor soil, New Phytol., 170, 345-356, https://doi.org/10.1111/j.14698137.2006.01658.x, 2006.

Kang, L., Han, X. G., Zhang, Z. B., and Sun, O. J.: Grassland ecosystems in China: review of current knowledge and research advancement, Philos. T. R. Soc. B, 362, 997-1008, https://doi.org/10.1098/rstb.2007.2029, 2007.

Karhu, K., Auffret, M. D., Dungait, J. A., Hopkins, D. W., Prosser, J. I., Singh, B. K., Subke, J. A., Wookey, P. A., Agren, G. I., Sebastia, M. T., Gouriveau, F., Bergkvist, G., Meir, P., Nottingham, A. T., Salinas, N., and Hartley, I. P.: Temperature sensitivity of soil respiration rates enhanced by microbial community response, Nature, 513, 81-84, https://doi.org/10.1038/nature13604, 2014.

Keith, H., Jacobsen, K. L., and Raison, R. J.: Effects of soil phosphorus availability, temperature and moisture on soil respiration in Eucalyptus pauciflora forest, Plant Soil, 190, 127-141, https://doi.org/10.1023/A:1004279300622, 1997.

Kwon, M. J., Natali, S. M., Hicks, C. E., Schuur, E. A., Steinhof, A., Crummer, K. G., Zimov, N., Zimov, S. A., Heimann, M., Kolle, O., and Göckede, M.: Drainage enhances modern soil carbon contribution but reduces old soil carbon contribution to ecosystem respiration in tundra ecosystems, Glob. Change Biol., 25, 1315-1325, https://doi.org/10.1111/gcb.14578, 2019.

Li, H. J., Yan, J. X., Yue, X. F., and Wang, M. B.: Significance of soil temperature and moisture for soil respiration in a Chinese mountain area, Agr. Forest Meteorol., 148, 490-503, https://doi.org/10.1016/j.agrformet.2007.10.009, 2008.

Lin, X. W., Zhang, Z. H., Wang, S. P., Hu, Y. G., Xu, G. P., Luo, C. Y., Chang, X. F., Duan, J. C., Lin, Q. Y., Xu, B., Wang, Y. F., Zhao, X. Q., and Xie, Z. B.: Response of ecosystem respiration to warming and grazing during the growing seasons in the alpine meadow on the Tibetan plateau, Agr. Forest Meteorol., 151, 792802, https://doi.org/10.1016/j.agrformet.2011.01.009, 2011.

Litton, C. M. and Giardina, C. P.: Below-ground carbon flux and partitioning: global patterns and response to temperature, Funct. Ecol., 22, 941-954, https://doi.org/10.1111/j.13652435.2008.01479.x, 2008.

Liu, L., Wang, X., Lajeunesse, M. J., Miao, G., Piao, S., Wan, S., Wu, Y., Wang, Z., Yang, S., Li, P., and Deng, M.: A cross-biome synthesis of soil respiration and its determinants under simulated precipitation changes, Glob. Change Biol., 22, 1394-1405, https://doi.org/10.1111/gcb.13156, 2016.

Liu, L. T., Hu, C. S., Yang, P. P., Ju, Z. Q., Olesen, J. E., and Tang, J. W.: Effects of experimental warming and nitrogen addition on soil respiration and $\mathrm{CH}_{4}$ fluxes from crop rotations of winter wheat-soybean/fallow, Agr. Forest Meteorol., 207, 38-47, https://doi.org/10.1016/j.agrformet.2015.03.013, 2015.

Liu, T., Xu, Z. Z., Hou, Y. H., and Zhou, G. S.: Effects of warming and changing precipitation rates on soil respiration over two 
years in a desert steppe of northern China, Plant Soil, 400, 15-27, https://doi.org/10.1007/s11104-015-2705-0, 2016.

Liu, W. X., Zhang, Z., and Wan, S. Q.: Predominant role of water in regulating soil and microbial respiration and their responses to climate change in a semiarid grassland, Glob. Change Biol., 15, 184-195, https://doi.org/10.1111/j.1365-2486.2008.01728.x, 2009.

Liu, W. X., Jiang, L., Hu, S. J., Li, L. H., Liu, L. L., and Wan, S. Q.: Decoupling of soil microbes and plants with increasing anthropogenic nitrogen inputs in a temperate steppe, Soil Biol. Biochem., 72, 116-122, https://doi.org/10.1016/j.soilbio.2014.01.022, 2014.

Liu, X. Z., Wan, S. Q., Su, B., Hui, D. F., and Luo, Y. Q.: Response of soil $\mathrm{CO}_{2}$ efflux to water manipulation in a tallgrass prairie ecosystem, Plant Soil, 240, 213-223, https://doi.org/10.1023/a:1015744126533, 2002.

Lloyd, J. and Taylor, J. A.: On the temperature dependence of soil respiration, Funct. Ecol., 8, 315-323, https://doi.org/10.2307/2389824, 1994.

Luo, Y. Q., Wan, S. Q., Hui, D. F., and Wallace, L. L.: Acclimatization of soil respiration to warming in a tall grass prairie, Nature, 413, 622-625, https://doi.org/10.1038/35098065, 2001.

Ma, Q., Yu, H., Liu, X., Xu, Z., Zhou, G., and Shi, Y.: Climatic warming shifts the soil nematode community in a desert steppe, Climatic Change, 150, 243-258, https://doi.org/10.1007/s10584018-2277-0, 2018.

Ma, Y. C., Piao, S. L., Sun, Z. Z., Lin, X., Wang, T., Yue, C., and Yang, Y.: Stand ages regulate the response of soil respiration to temperature in a Larix principisrupprechtii plantation, Agr. Forest Meteorol., 184, 179-187, https://doi.org/10.1016/j.agrformet.2013.10.008, 2014.

Maestre, F. T., Salguero-Gómez, R., and Quero, J. L.: It is getting hotter in here: determining and projecting the impacts of global environmental change on drylands, Philos. T. R. Soc. B., 367, 3062-3075, https://doi.org/10.1098/rstb.2011.0323, 2012.

Martins, C. S. C., Macdonald, C. A., Anderson, I. C., and Singh, B. K.: Feedback responses of soil greenhouse gas emissions to climate change are modulated by soil characteristics in dryland ecosystems, Soil Biol. Biochem., 100, 21-32, https://doi.org/10.1016/j.soilbio.2016.05.007, 2016.

Meisner, A., Rousk, J., and Bååth, E.: Prolonged drought changes the bacterial growth response to rewetting, Soil Biol. Biochem., 88, 314-322, https://doi.org/10.1016/j.soilbio.2015.06.002, 2015.

Meyer, N., Welp, G., and Amelung, W.: The temperature sensitivity $\left(Q_{10}\right)$ of soil respiration: controlling factors and spatial prediction at regional scale based on environmental soil classes, Global Biogeochem. Cy., 32, 306-323, https://doi.org/10.1002/2017GB005644, 2018.

Moncrieff, J. B. and Fang, C.: A model for soil $\mathrm{CO}_{2}$ production and transport 2: application to a Florida Pinus elliotte plantation, Agr. Forest Meteorol., 95, 237-256, https://doi.org/10.1016/S01681923(99)00035-0, 1999.

Moyano, F. E., Vasilyeva, N., Bouckaert, L., Cook, F., Craine, J., Curiel Yuste, J., Don, A., Epron, D., Formanek, P., Franzluebbers, A., Ilstedt, U., Kätterer, T., Orchard, V., Reichstein, M., Rey, A., Ruamps, L., Subke, J.-A., Thomsen, I. K., and Chenu, C.: The moisture response of soil heterotrophic respiration: in- teraction with soil properties, Biogeosciences, 9, 1173-1182, https://doi.org/10.5194/bg-9-1173-2012, 2012.

Moyano, F. E., Manzoni, S., and Chenu, C.: Responses of soil heterotrophic respiration to moisture availability: an exploration of processes and models, Soil Biol. Biochem., 59, 72-85, https://doi.org/10.1016/j.soilbio.2013.01.002, 2013.

Munson, S. M., Benton, T. J., Lauenroth, W. K., and Burke, I. C.: Soil carbon flux following pulse precipitation events in the shortgrass steppe, Ecol. Res., 25, 205-211, https://doi.org/10.1007/s11284-009-0651-0, 2009.

Nelson, D. W. and Sommers, L. E.: Dry combustion method using medium temperature resistance furnace, in: Methods of Soil Analysis, Part 2. Chemical and Microbial Properties, edited by: Page, A. L., Miller, R. H., and Keeney, D. R., Madison, WI, American Society of Agronomy and Soil Science Society of America, 539-579, 1982.

Prietzel, J., Zimmermann, L., Schubert, A., and Christophel, D.: Organic matter losses in German Alps forest soils since the 1970s most likely caused by warming, Nat. Geosci., 9, 543-548, https://doi.org/10.1038/ngeo2732, 2016.

Reynolds, L. L., Johnson, B. R., Pfeifer-Meister, L., and Bridgham, S. D.: Soil respiration response to climate change in $\mathrm{Pa}-$ cific Northwest prairies is mediated by a regional Mediterranean climate gradient, Glob. Change Biol., 21, 487-500, https://doi.org/10.1111/gcb.12732, 2015.

Rinnan, R., Michelsen, A., Bååth, E., and Jonasson, S.: Fifteen years of climate change manipulations alter soil microbial communities in a subarctic heath ecosystem, Glob. Change Biol., 13, 2839, https://doi.org/10.1111/j.1365-2486.2006.01263.x, 2007.

Rinnan, R., Stark, S., and Tolvanen, A.: Responses of vegetation and soil microbial communities to warming and simulated herbivory in a subarctic heath, J. Ecol., 97, 788-800, https://doi.org/10.1111/j.1365-2745.2009.01506.x, 2009.

Roby, M. C., Scott, R. L., Barron-Gafford, G. A., Hamerlynck, E. P., and Moore, D. J.: Environmental and vegetative controls on soil $\mathrm{CO}_{2}$ efflux in three semiarid ecosystems, Soil Syst., 3, 6, https://doi.org/10.3390/soilsystems3010006, 2019.

Romero-Olivares, A. L., Allison, S. D., and Treseder, K. K.: Soil microbes and their response to experimental warming over time: A meta-analysis of field studies, Soil Biol. Biochem., 107, 32 40, https://doi.org/10.1016/j.soilbio.2016.12.026, 2017.

Ru, J., Zhou, Y., Hui, D., Zheng, M., and Wan, S.: Shifts of growing-season precipitation peaks decrease soil respiration in a semiarid grassland, Glob. Change Biol., 24, 1001-1011, https://doi.org/10.1111/gcb.13941, 2018.

Sánchez-Rodríguez, A. R., Nie, C., Hill, P. W., Chadwick, D. R., and Jones, D. L.: Extreme flood events at higher temperatures exacerbate the loss of soil functionality and trace gas emissions in grassland, Soil Biol. Biochem., 130, 227-236, https://doi.org/10.1016/j.soilbio.2018.12.021, 2019.

Savage, K., Davidson, E. A., Richardson, A. D., and Hollinger, D. Y.: Three scales of temporal resolution from automated soil respiration measurements, Agr. Forest Meteorol., 149, 2012-2021, https://doi.org/10.1016/j.agrformet.2009.07.008, 2009.

Schlesinger, W. H.: Carbon balance in terrestrial detritus, Annu. Rev. Ecol. Evol. S., 8, 51-81, https://doi.org/10.1146/annurev.es.08.110177.000411, 1977.

Shen, Z. X., Li, Y. L., and Fu, G.: Response of soil respiration to short-term experimental warming and pre- 
cipitation pulses over the growing season in an alpine meadow on the Northern Tibet, Appl. Soil Ecol., 90, 35-40, https://doi.org/10.1016/j.apsoil.2015.01.015, 2015.

Sierra C. A., Trumbore S. E., Davidson, E. A., Vicca, S., and Janssens, I.: Sensitivity of decomposition rates of soil organic matter with respect to simultaneous changes in temperature and moisture, J. Adv. Model. Earth Sy., 7, 335-356, https://doi.org/10.1002/2014MS000358, 2015.

Skopp, J., Jawson, M. D., and Doran, J. W.: Steady-state aerobic microbial activity as a function of soil water content, Soil Sci. Soc. Am. J., 54, 1619-1625, https://doi.org/10.2136/sssaj1990.03615995005400060018x, 1990.

Song, W. M., Chen, S. P., Wu, B., Zhu, Y. J., Zhou, Y. D., Lu, Q., and Lin, G. H.: Simulated rain addition modifies diurnal patterns and temperature sensitivities of autotrophic and heterotrophic soil respiration in an arid desert ecosystem, Soil Biol. Biochem., 82, 143-152, https://doi.org/10.1016/j.soilbio.2014.12.020, 2015.

Sponseller, R. A.: Precipitation pulses and soil $\mathrm{CO}_{2}$ flux in a Sonoran Desert ecosystem, Glob. Change Biol., 13, 426-436, https://doi.org/10.1111/j.1365-2486.2006.01307.x, 2007.

Thakur, M. P., Del Real, I. M., Cesarz, S., Steinauer, K., Reich, P. B., Hobbie, S., Ciobanu, M., Rich, R., Worm, K., and Eisenhauer, N.: Soil microbial, nematode, and enzymatic responses to elevated $\mathrm{CO}_{2}, \mathrm{~N}$ fertilization, warming, and reduced precipitation, Soil Biol. Biochem., 135, 184-193, https://doi.org/10.1016/j.soilbio.2019.04.020, 2019.

Tucker, C. L. and Reed, S. C.: Low soil moisture during hot periods drives apparent negative temperature sensitivity of soil respiration in a dryland ecosystem: a multi-model comparison, Biogeochemistry, 128, 155-169, https://doi.org/10.1007/s10533016-0200-1, 2016.

Tucker, C. L., Bell, J., Pendall, E., and Ogle, K.: Does declining carbon-use efficiency explain thermal acclimation of soil respiration with warming? Glob. Change Biol., 19, 252-263, https://doi.org/10.1111/gcb.12036, 2013.

Wan, S. Q., Norby, R. J., Pregitzer, K. S., Ledford, J., and O’Neill, E. G.: $\mathrm{CO}_{2}$ enrichment and warming of the atmosphere enhance both productivity and mortality of maple tree fine roots, New Phytol., 162, 437-446, https://doi.org/10.1111/j.14698137.2004.01034.x, 2004.

Wan, S. Q., Hui, D. F., Wallace, L., and Luo, Y. Q.: Direct and indirect effects of experimental warming on ecosystem carbon processes in a tallgrass prairie, Global Biogeochem. Cy., 19, 113, https://doi.org/10.1029/2004GB002315, 2005.

Wan, S. Q., Norby, R. J., Ledford, J., and Weltzin, J. F.: Responses of soil respiration to elevated $\mathrm{CO}_{2}$, air warming, and changing soil water availability in a model old-field grassland, Glob. Change Biol., 13, 2411-2424, https://doi.org/10.1111/j.13652486.2007.01433.x, 2007.

Wang, Y., Hao, Y., Cui, X. Y., Zhao, H., Xu, C., Zhou, $\mathrm{X}$., and $\mathrm{Xu}, \mathrm{Z}$.: Responses of soil respiration and its components to drought stress, J. Soil. Sediment., 14, 99-109, https://doi.org/10.1007/s11368-013-0799-7, 2014.

$\mathrm{Wu}$, H. J. and Lee, X.: Short-term effects of rain on soil respiration in two New England forests, Plant Soil, 338, 329-342, https://doi.org/10.1007/s11104-010-0548-2, 2011.

Xu, W., Yuan, W., Cui, L., Ma, M., and Zhang, F.: Responses of soil organic carbon decomposition to warming de- pend on the natural warming gradient, Geoderma, 343, 10-18, https://doi.org/10.1016/j.geoderma.2019.02.017, 2019.

Xu, Z., Shimizu, H., Ito, S., Yagasaki, Y., Zou, C., Zhou, G., and Zheng, Y.: Effects of elevated $\mathrm{CO}_{2}$, warming and precipitation change on plant growth, photosynthesis and peroxidation in dominant species from North China grassland, Planta, 239, 421-435, https://doi.org/10.1007/s00425-013-1987-9, 2014.

Xu, Z., Hou, Y., Zhang, L., Tao, L., and Zhou, G.: Ecosystem responses to warming and watering in typical and desert steppes, Sci. Rep.-UK, 6, 34801, https://doi.org/10.1038/srep34801, 2016.

Yan, M. F., Zhou, G. S., and Zhang, X. S.: Effects of irrigation on the soil $\mathrm{CO}_{2}$ efflux from different poplar clone plantations in arid northwest China, Plant Soil, 375, 89-97, https://doi.org/10.1007/s11104-013-1944-1, 2013.

Yan, Z. B., Bond-Lamberty, K. E., Todd-Brown, V. L., Bailey, S., Li, C., Liu, C. Q., and Liu, C.: A moisture function of soil heterotrophic respiration that incorporates microscale processes, Nat. Commun., 9, 2562, https://doi.org/10.1038/s41467018-04971-6, 2018

Yin, X., Goudriaan, J. A. N., Lantinga, E. A., Vos, J. A. N., and Spiertz, H. J.: A flexible Gompertz function of determinate growth, Ann. Bot., 91, 361-371, https://doi.org/10.1093/aob/mcg029, 2003.

Yu, H., Ma, Q., Liu, X., Xu, Z., Zhou, G., and Shi, Y.: Short-and long-term warming alters soil microbial community and relates to soil traits, Appl. Soil Ecol., 131, 22-28, https://doi.org/10.1016/j.apsoil.2018.07.006, 2018.

Yu, H. Y., Chen, Y. T., Xu, Z. Z., and Zhou, G. S.: Analysis of relationships among leaf functional traits and economics spectrum of plant species in the desert steppe of Nei Mongol, Chin. J. Plant Ecol., 38, 1029-1040, https://doi.org/10.3724/SP.J.1258.2014.00097, 2014.

Yu, H. Y., Xu, Z. Z., Zhou, G. S., and Shi, Y. H.: The data for the article entitled "Soil carbon release responses to long-term versus short-term climatic warming in an arid ecosystem" [Data set], Zenodo, https://doi.org/10.5281/zenodo.3546062, 2019.

Zhang, C. P., Niu, D. C., Hall, S. J., Wen, H. Y., Li, X. D., Fu, H., Wan, C. G., and Elser, J. J.: Effects of simulated nitrogen deposition on soil respiration components and their temperature sensitivities in a semiarid grassland, Soil Biol. Biochem., 75, 113123, https://doi.org/10.1016/j.soilbio.2014.04.013, 2014.

Zhang, N. L., Wan, S. Q., Li, L. H., Bi, J., Zhao, M. M., and Ma, K. P.: Impacts of urea $\mathrm{N}$ addition on soil microbial community in a semi-arid temperate steppe in northern China, Plant Soil, 311, 19-28, https://doi.org/10.1007/s11104-008-9650-0, 2008.

Zhang, W., Parker, K. M., Luo, Y., Wan, S., Wallace, L. L., and $\mathrm{Hu}$, S.: Soil microbial responses to experimental warming and clipping in a tallgrass prairie, Glob. Change Biol., 11, 266-277, https://doi.org/10.1111/j.1365-2486.2005.00902.x, 2005. 